Красинский Владислав Вячеславович кандидат юридических наук, эксперт Российского общественного института избирательного права (РОИИП)

Начальнику отдела регионального законодательства ЦИК России Киселевой Наталье Владимировне, трагически погибшей от терроризма в московском метро 6 февраля 2004 г., посвящается

Источник публикации: Красинский В.B. Участие организованных преступных групп в избирательных кампаниях // Политика и общество. 2008. № 4. С. 7-13; www.krasinskiy.ru

\title{
УЧАСТИЕ ОРГАНИЗОВАННЫХ ПРЕСТУПНЫХ ГРУПП В ИЗБИРАТЕЛЬНЫХ КАМПАНИЯХ
}

Развитие экономических отношений в Российской Федерации, проходившее в период заметного ослабления регулирующей роли государства в экономике, отсутствие необходимой нормативной базы рыночного хозяйствования, широкомасштабный раздел государственной собственности с использованием незаконных методов и средств привели к массовому вовлечению в экономические процессы представителей организованных преступных групп и постепенному установлению криминального контроля над значительным числом хозяйствующих субъектов ${ }^{1}$.

Заинтересованность преступных групп в постоянном наращивании своих доходов, прямая зависимость официальной и теневой экономической деятельности от политической конъюнктуры в Российской Федерации, желание обеспечить личную безопасность обусловили стремление лидеров криминалитета легализовать свой статус и принимать активное участие в принятии политических решений.

Удобным каналом реализации указанных криминальных интересов стало участие организованных преступных групп в избирательных кампаниях, проходящих в Российской Федерации.

В качестве цели участия организованных преступных групп в избирательных кампаниях следует назвать завоевание государственной власти, связанное с последующей переориентацией государственных и

1 Здесь и далее под организованной преступной группой понимается устойчивая и сплоченная преступная организация, имеющая иерархическую структуру и созданная для совершения тяжких или особо тяжких преступлений. Организаторы, руководители, участники и иные представители организованной преступной группы определяются как криминалитет. 
муниципальных выборных институтов на постоянное обслуживание криминальных интересов.

Достижение указанной цели связано с необходимостью решения преступными группами ряда перспективных задач.

Перспективные задачи участия организованных преступных групп в избирательных кампаниях можно классифицировать на две основные группы: политические и экономические.

К числу политических задач организованных преступных групп, связанных с избранием представителей криминалитета в органы государственной власти и местного самоуправления, следует отнести ${ }^{2}$ :

- замещение выборных должностей муниципальных образований с целью последующего использования должностных полномочий в интересах организованных преступных групп;

- формирование в федеральных и региональных органах государственной власти депутатского корпуса, лоббирующего принятие нормативных правовых актов, политических, административных и иных официальных решений в интересах организованных преступных групп;

- приобретение иммунитетов выборных должностных лиц и депутатской неприкосновенности.

Перспективные экономические задачи организованных преступных групп, связанные с избранием их представителей в органы государственной власти и местного самоуправления, включают:

- легальный передел рынков сырья, недвижимости, товаров и услуг в интересах организованных преступных групп;

- установление контроля над прибыльными бюджетообразующими предприятиями и высокорентабельными отраслями экономики (строительство, топливно-энергетический комплекс, добывающая промышленность, учреждения кредитно-финансовой сферы);

- неправомерное получение дополнительных льгот и преференций (экспортно-импортные операции, налоги, лицензионная деятельность, квотирование)

- неправомерное получение кредитов и управление бюджетными средствами в интересах организованных преступных групп.

Комплекс задач участия в избирательных кампаниях, стоящих перед организованными преступными группами, определяет выбор представителями криминалитета соответствующих методов борьбы за государственную власть в условиях выборов.

${ }^{2} \mathrm{~K}$ числу органов государственной власти и местного самоуправления в Российской Федерации, формируемых путем выборов, относятся Президент Российской Федерации, Государственная Дума Федерального Собрания Российской Федерации, законодательные органы государственной власти субъектов Российской Федерации, представительные органы муниципальных образований, выборные должностные лица муниципальных образований. Необходимо отметить, что данных, свидетельствующих об устремлениях представителей криминалитета быть избранными на пост Президента Российской Федерации, до настоящего времени получено не было. С учетом этого автор не рассматривает участие преступных групп в выборах Президента Российской Федерации. 
В ходе подготовки и проведения выборов представители организованных преступных групп используют наряду с разрешенными законом методами политической борьбы следующие методы:

- подкуп руководства политических партий, региональных отделений политических партий, членов избирательных комиссий, судей, сотрудников правоохранительных органов, журналистов. (Как показывает практика, на подкуп должностных лиц - объектов заинтересованности организованных преступных групп - тратится 2/3 от общего объема преступных доходов. Введение пропорциональной системы по выборам депутатов Государственной Думы Федерального Собрания Российской Федерации и законодательных органов государственной власти субъектов Российской Федерации принципиально не изменило ситуацию. Если раньше представители организованных преступных групп избирались от подконтрольных им территорий - соответствующих одномандатных или многомандатных округов или покупали «проходные» места в партийных списках, то теперь существенно возросла роль партийной коррупции в политическом процессе).

- подкуп избирателей;

- шантаж партийных функционеров, членов избирательных комиссий, журналистов, судей;

- компрометация честных и компетентных должностных лиц и сотрудников правоохранительных органов;

- принудительная доставка избирателей транспортом кандидата на избирательные участки;

- уничтожение имущества (поджоги помещений, транспорта, общественных приемных и избирательных штабов кандидатов);

- насильственные действия в отношении политических конкурентов, членов их семей и родственников (в том числе совершение убийств) ${ }^{3}$.

Реализация задач участия организованных преступных групп в избирательных кампаниях зависит не только от используемых представителями криминалитета методов борьбы за государственную власть в условиях выборов, но и от влияния ряда ключевых факторов.

Необходимо различать факторы, способствующие реализации задач участия организованных преступных групп в избирательных кампаниях, а также факторы, затрудняющие реализацию задач участия организованных преступных групп в избирательных кампаниях.

Среди наиболее значимых факторов, способствующих реализации задач участия организованных преступных групп в избирательных кампаниях, можно выделить политико-правовой, материально-технический, организационный и идеологический факторы.

Политико-правовой фактор включает просчеты руководства страны и высших должностных лиц субъектов Российской Федерации в сочетании с их

3 Например, убийство в 2006 г. кандидата на пост Главы Администрации г. Дальнегорска Приморского края Д. Фотьянова. См. Заявление Президиума Генерального Совета «Единой России» от 20.10.2006 «Не допустим криминал во власть». 
нежеланием (боязнью) противодействовать криминализации органов государственной власти и местного самоуправления. $\mathrm{Ha}$ практике представители криминалитета уже давно реализуют отдельные государственные полномочия и функции государственных и муниципальных органов ${ }^{4}$. Кандидаты организованных преступных групп выражают интересы ряда социальных групп российского общества и располагают поддержкой в обществе ${ }^{5}$. По данным проведенного Фондом «Общественное мнение» Всероссийского опроса городского и сельского населения 44 субъектов Российской Федерации, 4 \% опрошенных граждан полагают, что навести порядок в государстве могут только представители организованных преступных групп, потому что «криминал привык к дисциплине», «порядка больше в их среде». 2\% респондентов считают представителей уголовной среды честными, справедливыми, умными людьми с большим жизненным опытом, умеющими держать данное слово («они жизнь лучше понимают», «они зачастую более порядочные, чем политики») ${ }^{6}$.

Другой составляющей политико-правового фактора является отсутствие эффективных нормативно-правовых ограничений по избранию представителей организованных преступных групп в органы государственной власти и местного самоуправления. Лица, находящиеся в розыске или под следствием, могут быть зарегистрированы в качестве кандидатов и избраны. Важно подчеркнуть, что по действующему законодательству о выборах наличие оперативно-значимой информации о связях кандидатов с представителями организованных преступных групп не является основанием для отказа от регистрации кандидата (списка кандидатов), исключения кандидата из списка, аннулирования регистрации кандидата (списка кандидатов) или отмены регистрации кандидата (списка кандидатов $)^{7}$.

Важную роль в реализации задач участия организованных преступных групп в избирательных кампаниях играет материально-технический фактор. Дефициты местных и региональных бюджетов, с одной стороны, и наличие значительных материальных средств в распоряжении организованных

\footnotetext{
${ }_{5}^{4}$ Например, «теневую юстицию».

5 Социальной базой устойчивой поддержки представителей криминалитета на выборах выступают, главным образом, лица, находящиеся под следствием в местах содержания под стражей (СИЗО, ИВС), ранее и неоднократно судимые, их связи, молодежь. Криминальный потенциал населения, готового оправдать и поддержать преступную деятельность, значителен. По данным экспертов, в России «школу» исправительных учреждений прошли 15-18 млн человек; численность лиц, совершивших латентные преступления, приближается к 15 млн; количество ежегодно совершаемых преступлений - около 3 млн; примерно 5 млн преступлений официально считаются не раскрытыми. Следовательно, 35-40 млн. человек (практически каждый третий взрослый россиянин) причастны к преступной деятельности. См.: Криминология: уч. для вузов / под ред. В.Д. Малкова. М.: ЗАО Юстицинформ, 2006. С. 421.

См.: Петрова $A$. Криминал во власти - обычное явление? //bd.fom.ru/report/map/projects. См. также. Труд. 2004. 10 августа. № 148.

7 См. П. 24 ст. 38, ст. 76 Федерального закона «Об основных гарантиях избирательных прав и права на участие в референдуме граждан Российской Федерации», ст. 44 и 91 Федерального закона «О выборах депутатов Государственной Думы Федерального Собрания Российской Федерации», ст. 39 и 84 Федерального закона «О выборах Президента Российской Федерации».
} 
преступных групп, с другой стороны, способствовали формированию заинтересованности органов власти в сотрудничестве с организованными преступными группами, а в дальнейшем и зависимости государственных и муниципальных органов от представителей криминалитета. Экономическая состоятельность организованных преступных групп и подконтрольных им финансово-промышленных структур позволяет представителям криминалитета выступать основными спонсорами избирательных кампаний, контролировать деятельность судей, избирательных комиссий, правоохранительных органов и СМИ. В период подготовки и проведения выборов кандидаты, представляющие интересы преступных групп, нередко демонстрируют готовность и умение решать социально-значимые вопросы: асфальтируют дороги, устанавливают памятные доски воинам-участникам Великой Отечественной Войны, строят детские площадки, стремятся участвовать в осуществлении экономических программ и приоритетных национальных проектов.

Организационный фактор, способствующий реализации задач участия преступных групп в избирательных кампаниях, проявляется в том, что команды кандидатов организованных преступных групп, как правило, обладают лучшим финансированием, связанной с ним широкой возможностью подбора кадров профессиональных организаторов выборов, а также выстроенной системой управления, в которой сочетаются постановка четких и реальных задач, минимизация бюрократической волокиты, распределение ролей, строгая подчиненность, контроль и взаимная ответственность исполнителей ${ }^{8}$.

Bce большее значение в успехе представителей криминалитета на выборах приобретает идеологический фактор. Как свидетельствует электоральная практика, в общественном сознании населения ряда субъектов Российской Федерации сформировались толерантность и симпатии среди населения в отношении избранных в органы государственной власти и местного самоуправления представителей организованных преступных групп и связанных с уголовной средой кандидатов на выборные должности. В ряде субъектов Российской Федерации представители криминалитета пользуются уважением среди населения ${ }^{9}$. Черты уголовной субкультуры (культ насилия и паразитизма, антиобщественные нормы - обычаи, азартные игры, жаргон,

8 По данным опроса граждан г. Омска, проведенного в апреле 2002 г., 25, 3\% респондентов среди привлекательных черт представителей криминалитета назвали деловитость и умение решать вопросы. См.: Санин B.A. Бандиты и мы / Преступность в России и борьба с ней: региональный аспект. М., Российская криминологическая ассоциация, 2003. С. 83.

9 Зачастую сами представители государственной власти укрепляют веру населения во всесилие бандитов. Как можно относиться к государственным и муниципальным органам, руководство которых охотно принимает перечисленные криминальными авторитетами в порядке благотворительности денежные средства? Как можно уважать государственную власть, которая себя (не граждан!) от представителей криминалитета защитить не может? Зависимость государственной власти от преступных групп влечет за собой усиление криминального влияния во всех сферах общественной жизни. 
грубая матершина, клички, татуировки, блатные песни) проникли в повседневную жизнь и регулярно воспроизводятся в отдельных социальных группах российского общества ${ }^{10}$. Необходимо отметить, что представители организованных преступных групп активно поддерживают усиление криминального влияния в обществе, в том числе в молодежной среде. Известны случаи организации спортивных секций, клубов по интересам, развлекательных центров и дискотек, находящихся под влиянием представителей организованной преступности и финансирующихся из их источников. Менталитет «братков» распространился даже в федеральных органах государственной власти и управления.

Следует также выделить факторы, затрудняющие реализацию задач участия организованных преступных групп в избирательных кампаниях. К ним относятся:

соответствие проводимой органами государственной власти и местного самоуправления политики интересам борьбы с организованной преступностью;

поддержка населением принимаемых руководством и должностными лицами органов государственной власти и местного самоуправления мер по борьбе с организованной преступностью;

тесная координация деятельности правоохранительных органов, СМИ и общественных организаций по недопущению представителей криминалитета в органы государственной власти и местного самоуправления;

совершенствование законодательства о выборах путем установления правовых ограничений на избрание в органы государственной власти и местного самоуправления лиц, находящихся под следствием, в розыске, имеющих судимость за совершение тяжких или особо тяжких преступлений и Т.П.;

ограничение числа и содержания иммунитетов выборных должностных лиц и депутатской неприкосновенности.

Процесс проникновения криминалитета в органы государственной власти и местного самоуправления Российской Федерации складывался из двух основных стадий.

На стадии первичной политизации организованной преступности (19951999 гг.) происходило наиболее активное продвижение организованными преступными группами своих кандидатов в органы государственной власти и местного самоуправления в условиях выборов ${ }^{11}$. Данное обстоятельство во

${ }^{10}$ См.: Маликов Б.3. Усиление криминала в сфере духовности общества и некоторые проблемы укрепления правопорядка / Проблемы правовой культуры. М, Криминологическая ассоциация, 2002. С. 7. См. также Анисимков B.M. Криминальная субкультура и ее нейтрализация в ИУ России. Автореф. дис. д-ра. юрид. наук. М.: Академия управления МВД РФ, 1998. С.3.

11 Необходимо подчеркнуть, что проникновение криминалитета в органы государственной власти и местного самоуправления осуществлялось и осуществляется далеко не только в условиях выборов. Привлечение депутатов, выборных должностных лиц, конкретных федеральных, региональных и муниципальных служащих (в ряде случаев - их окружения) к долговременному возмездному конфиденциальному сотрудничеству 
многом обусловлено тем, что до 1999 г. в законодательстве о выборах отсутствовали положения, связанные с необходимостью кандидатов сообщать избирательным комиссиям сведения о привлечении их к уголовной ответственности. В связи с вступлением в силу Федерального закона от 30.03.1999 г. № 55-Ф3 «О внесении изменений и дополнений в Федеральный закон «Об основных гарантиях избирательных нрав и права на участие в референдуме граждан Российской Федерации» была закреплена обязанность указания кандидатами на выборные должности сведений о неснятых или непогашенных судимостях с уточнением номера (номеров) и наименования статьи Уголовного кодекса Российской Федерации, на основании которой был осужден кандидат, а также статьи (статей) уголовного кодекса, принятого в соответствии с Основами уголовного законодательства Союза ССР и союзных республик, статьи (статей) закона иностранного государства, если кандидат был осужден в соответствии с названными законодательными актами за деяния, признаваемые действующим Уголовным кодексом Российской Федерации преступлением.

Ускорение первичной политизации организованной преступности было тесно связано с произошедшим ранее изменением структуры криминального сообщества. Наряду с «ворами в законе» активную роль в уголовной среде стали играть криминальные лидеры «отморозки» («беспредельщики»), игнорирующие и грубо нарушающие воровские традиции (национальная неприязнь, отказ от запрета на участие в политической и общественной жизни, совершение убийств, посягательства на «законников», отказ от «общаков») ${ }^{12}$. Данная часть представителей преступной среды в 90-х гг. проявляла наибольшую активность, связанную с избранием в органы государственной власти и местного самоуправления.

После достижения этой цели представители криминалитета легализовали свой статус в органах государственной власти и местного самоуправления, получили законный доступ к финансовым ресурсам и стали широко использовать возможности государственного аппарата для осуществления и воспроизводства преступной деятельности. На данной стадии проникновения криминалитета в органы власти и произошло окончательное сращивание организованных преступных групп с элементами государственного механизма и местного самоуправления в ряде субъектов Российской Федерации.

(коррумпирование государственного механизма и местного самоуправления) является приоритетной задачей разведки и контрразведки любой организованной преступной группы. Однако следует иметь в виду, что не каждый чиновник-взяточник представляет интерес для организованных преступных групп и закономерно связан с организованной преступной деятельностью.

12 «Вор в законе» - это признанный лидер преступного мира, имеющий, как правило, большой криминальный опыт и последовательно придерживающийся норм воровского сообщества. Подробней характеристику лидеров и участников организованных преступных формирований см. Гриб В.Г. Противодействие организованной преступности. М.: Инфра-М, 2001. С. 43-46; Криминология: уч. для вузов / под ред. В.Д. Малкова. М.: ЗАО Юстицинформ, 2006. С. 395-396. 
Переход на пропорциональную систему выборов в Государственную Думу Федерального Собрания Российской Федерации, установление правовых ограничений на избрание в органы государственной власти и местного самоуправления лиц, имеющих на день голосования неснятую и непогашенную судимость за совершение тяжких и (или) особо тяжких преступлений, преступлений экстремистской направленности, детализация финансирования участия политических партий в выборах, ужесточение юридической ответственности за нарушение порядка финансирования избирательных кампаний, отзыв лицензий у ряда учреждений кредитнобанковской системы, подозреваемых в причастности к отмыванию денежных средств, высокая эффективность использования властных полномочий коррумпированных руководителей и должностных лиц федеральной и региональной систем государственного аппарата в интересах организованных преступных групп, не требующая личного представительства криминалитета в органах государственной власти и местного самоуправления, повлекли за собой и изменение тактики криминалитета по продвижению своих кандидатов в органы власти ${ }^{13}$.

Статистика региональных и муниципальных выборов, прошедших в 2006-2008 гг., свидетельствует о новых тенденциях участия организованных преступных групп в избирательных кампаниях.

Во-первых, в настоящее время заметно снизилось число представителей организованных преступных групп, непосредственно баллотирующихся в депутаты или на выборные должности. Сейчас лидеры уголовной среды предлагают перспективным кандидатам свое участие в финансировании избирательной кампании либо самостоятельно заблаговременно готовят для внедрения в органы государственной власти и местного самоуправления своих «незасвеченных» ставленников, не имеющих судимостей, не скомпрометировавших себя выявленными связями с организованными преступными группами.

Во-вторых, несмотря на легализацию статуса и доходов, никто из депутатов или выборных должностных лиц, являющихся лидерами уголовной среды, не распустил свои боевые группировки («боевиков»). Как правило, эти структуры действуют под прикрытием частных охранных предприятий или служб безопасности ${ }^{14}$. Таким образом, в ходе организации и проведения выборов у представителей организованных преступных групп сохраняется возможность использовать силовое воздействие на избирательный процесс для оказания влияния на принятие политических

13 См. Федеральный закон от 18.05.2005 г. № 51-Ф3 «О выборах депутатов Государственной Думы Федерального Собрания Российской Федерации»; Федеральный закон от 21.07.2005 г. № 93-Ф3 «О внесении изменений в законодательные акты Российской Федерации о выборах и референдумах и иные законодательные акты Российской Федерации»; Федеральный закон от 05.12.2006 г. № 225-Ф3 «О внесении изменений в Федеральный закон «Об основных гарантиях избирательных прав и права на участие в референдуме граждан Российской Федерации» и Гражданский процессуальный кодекс Российской Федерации» и др.

${ }_{14}$ В ряде случаев «боевики» оформляются в штат юридических лиц, подконтрольных преступным группам. 
решений, дестабилизации обстановки и устрашения населения. Кроме того, лидеры этнических преступных групп, действующих на территории Российской Федерации, могут использовать свои боевые подразделения в ходе межнациональных столкновений, периодически возникающих в отдельных субъектах Российской Федерации.

В-третьих, с учетом повышения роли политических партий в избирательном процессе важнейшей задачей уголовной разведки и контрразведки стало установление контроля организованных преступных групп над существующими политическими партиями (региональными отделениями политических партий) и продвижение своих представителей в органы государственной власти и местного самоуправления с использованием партийных структур.

B-четвертых, представителями организованных преступных групп практически перестало осуществляться отмывание денежных средств в ходе выборов. Данное обстоятельство обусловлено наличием у организованных преступных групп многообразных законных источников финансирования избирательных кампаний и ужесточением юридической ответственности за нарушение порядка финансирования выборов.

Указанные тенденции участия организованных преступных групп в избирательных кампаниях затрудняют целенаправленную деятельность правоохранительных органов по недопущению представителей криминалитета в органы государственной власти и местного самоуправления в ходе выборов и усиливают общественную опасность подобных процессов.

Общественная опасность избрания представителей организованных преступных групп в органы государственной власти и местного самоуправления проявляется с разных сторон ${ }^{15}$.

Замещение выборных должностей представителями организованных преступных групп неизбежно приводит к росту теневого экономического потенциала, находящегося под контролем криминалитета. Преступные группы получают доступ к управлению бюджетными средствами, распределению ресурсов и льгот, что позволяет им занимать лидирующие позиции в экономике субъектов Российской Федерации.

Принятие пролоббированных организованными преступными группами нормативных актов дискредитирует представительные органы государственной власти (местного самоуправления) и принимаемые депутатами законодательные акты. Осуществление преступной деятельности и законотворчество исключают совмещение в силу своей чужеродности. Правовое регулирование общественных отношений в интересах преступных групп влечет за собой необратимую деформацию правосознания широких слоев населения и усиливает правовой нигилизм.

${ }^{15}$ Перечисленные ниже проявления общественного вреда, как правило, относятся и к случаям оказания различных услуг представителям криминалитета победившими на выборах кандидатами и политическими партиями, финансировавшимися организованными преступными группами. 
Приобретение представителями криминалитета властных полномочий, иммунитетов выборных должностных лиц и депутатской неприкосновенности губительно сказывается на состоянии законности и борьбе с организованной преступностью. Представители уголовной среды, избранные в органы государственной власти и местного самоуправления, эффективно используют властные полномочия для борьбы со своими конкурентами, для неправомерного воздействия на сотрудников правоохранительных органов, прокуроров и судей. Сложность привлечения к ответственности представителей криминалитета, наделенных иммунитетами, поддержка преступными группами коррумпированных руководителей и сотрудников государственных, в том числе правоохранительных органов, способствуют увольнению из государственного аппарата честных сотрудников и квалифицированных специалистов ${ }^{16}$.

С учетом этого требуется незамедлительная и планомерная реализация комплекса общегосударственных (политических, правовых, организационнокадровых, информационно-пропагандистских) и специальных мер противодействия общественности и государственных органов продвижению организованными преступными группами своих кандидатов в органы государственной власти и местного самоуправления в условиях выборов.

Общегосударственные меры противодействия общественности и государственных органов продвижению организованными преступными группами своих кандидатов в органы государственной власти и местного самоуправления в условиях выборов должны быть направлены на обязательную ликвидацию причин криминализации органов государственной власти и местного самоуправления. Участие общественности и СМИ в борьбе с криминализацией органов власти является необходимым, так как нередко легализовавшиеся представители криминалитета не только не противодействуют продвижению организованными преступными группами своих кандидатов в органы государственной власти и местного самоуправления в условиях выборов, но и активно поддерживают подобные попытки, используя собственные государственно-властные полномочия («административный ресурс»).

К числу общегосударственных политических мер противодействия общественности и государственных органов продвижению организованными преступными группами своих кандидатов в органы государственной власти и местного самоуправления в условиях выборов относятся официальные

16 Глубоко ошибочной и опасной является точка зрения о бесполезности борьбы с уже легализовавшимися представителями криминалитета. Подобная попустительская позиция нередко оправдывает бездействие высших должностных лиц субъектов Российской Федерации и руководства правоохранительных органов и приводит к формированию на территории Российской Федерации криминально-государственных регионов, официально управляемых организованными преступными группами. Думается, что допущенные в государственной практике политико-юридические ошибки необходимо исправлять, а не мириться с ними. Какие бы посты сегодня не занимали бандиты, наименование должности, размах полезных связей и количество государственных наград не могут служить оправданием совершенным преступлениям. Юридическая ответственность должна быть неотвратимой для всех. 
поручения главы государства, высших должностных лиц субъектов Российской Федерации руководителям избирательных комиссий и правоохранительных органов по недопущению участия в политической жизни и избрания представителей криминалитета, разработка федеральных и региональных программ борьбы с криминализацией органов государственной власти и местного самоуправления, т.н. «антикриминальные пакты» политических партий перед федеральными и региональными выборами ${ }^{17}$. Для нейтрализации организованной преступности требуется, в первую очередь, политическая воля высших должностных лиц государства и регионов, а также согласованная последовательная деятельность общественности, СМИ и государственных органов.

Правовые меры борьбы с криминализацией органов государственной власти и местного самоуправления предусматривают совершенствование законодательства путем установления правовых ограничений на избрание в органы государственной власти и местного самоуправления лиц, находящихся в федеральном розыске, имеющих судимость (в том числе снятую и погашенную) за совершение тяжких или особо тяжких преступлений. В федеральных законах о выборах предлагается закрепить обязательность указания кандидатами в депутаты и (или) на выборные должности всех имеющихся судимостей (в т.ч. снятых и погашенных), а также информирования политическими партиями и избирательными комиссиями избирателей о всех судимостях кандидатов. В целях пресечения противоправной деятельности и подготовки материалов для привлечения к ответственности представителей криминалитета, избранных в органы государственной власти и местного самоуправления, предлагается использование института приостановления полномочий депутатов и выборных должностных лиц. С учетом этого Федеральный закон (в ред. от 05.07.1999 г. № 133-Ф3, с изм. от 02.03.2007 г.) «О статусе члена Совета Федерации и статусе депутата Государственной Думы Федерального Собрания Российской Федерации» представляется целесообразным дополнить статьей 4 : «Приостановление полномочий члена Совета Федерации, депутата Государственной Думы Федерального Собрания Российской Федерации» следующего содержания:

«1. Полномочия члена Совета Федерации, депутата Государственной Думы Федерального Собрания Российской Федерации приостанавливаются в случаях:

a) возбуждения уголовного дела в отношении члена Совета Федерации, депутата Государственной Думы Федерального Собрания Российской Федерации по статьям Уголовного кодекса Российской Федерации,

17 В качестве примера подобного «антикриминального пакта» можно привести «Соглашение о противодействии проникновению криминала во власть», подписанное 10.07.2006 г. в Екатеринбурге представителями «Единой России», ЛДПР, КПРФ, «Российской партии Пенсионеров», «Российской коммунистической рабочей партии, партии «Яблоко», «Патриоты России», «Демократической партии России», «Родина». 
предусматривающим наказание за совершение тяжких и (или) особо тяжких преступлений;

б) возбуждения уголовного дела в отношении члена Совета Федерации, депутата Государственной Думы Федерального Собрания Российской Федерации по статьям Уголовного кодекса Российской Федерации, предусматривающим наказание за совершение преступлений экстремистской направленности;

в) объявления члена Совета Федерации, депутата Государственной Думы Федерального Собрания Российской Федерации в федеральный розыск.

2. Решение о приостановлении полномочий члена Совета Федерации, депутата Государственной Думы Федерального Собрания Российской Федерации оформляется соответствующим постановлением Совета Федерации, Государственной Думы Федерального Собрания Российской Федерации, в котором определяется день приостановления полномочий члена Совета Федерации, депутата Государственной Думы Федерального Собрания Российской Федерации».

Аналогичные нормы можно было бы воспроизвести и в законодательстве субъектов Российской Федерации, определяющем статус депутатов и выборных должностных лиц.

Организационно-кадровые меры противодействия криминалитету должны охватывать две группы мер. Первая группа мер противодействия касается внутрипартийной кадровой политики: проверки кандидатов в члены партии, выявления фактов партийной коррупции и передачи собранных материалов правоохранительным органам, проверки членов партии, баллотирующихся по партийным спискам, исключения из партии лиц, скомпрометировавших себя связями с экстремистскими организациями и организованными преступными группами. Вторая группа мер связана с совершенствованием кадрового комплектования всей системы государственных органов. Следует констатировать, что до недавнего времени кадровая политика в органах государственной власти и управления была ориентирована преимущественно на привлечение мало проверенного контингента, не имеющего достаточной профессиональной подготовки и образования $^{18}$. В процессе противодействия общественности и государственных органов продвижению организованными преступными группами своих кандидатов в органы государственной власти и местного самоуправления в условиях выборов необходимо прогнозировать давление со стороны легализовавшихся представителей криминалитета (коррумпированных должностных лиц, представляющих криминальные интересы) на конкретных руководителей и должностных лиц,

18 См.: Юикова E.M. Граждане и власть: некоторые криминологические аспекты / Преступность и власть. Материалы конференции. М.: Российская криминологическая ассоциация, 2000. С. 31. 
осуществляющих борьбу с организованной преступностью, и заранее проработать меры по нейтрализации подобного давления и обеспечению безопасности задействованных государственных служащих, сотрудников правоохранительных органов, партийных функционеров, журналистов. При осуществлении сотрудничества органов внутренних дел, юстиции, федеральной службы безопасности, прокуратуры в борьбе с криминализацией органов власти с аппаратами полномочных представителей Президента Российской Федерации в федеральных округах нельзя исключать вероятных утечек оперативно-значимой информации представителям криминалитета. В связи с этим следует предусмотреть меры по локализации негативных последствий подобных утечек.

Меры информационно-пропагандистского противодействия общественности и государственных органов продвижению организованными преступными группами своих кандидатов в органы государственной власти и местного самоуправления в условиях выборов должны быть направлены на повышение правовой культуры общества. Особую роль представляется целесообразным уделить профилактической работе избирательных комиссий, правоохранительных органов, органов государственной власти субъектов Федерации в молодежной среде. Чрезвычайно важной является деятельность СМИ по консолидации российского общества и формированию негативного общественного мнения по отношению к деятельности преступных групп, криминальным лидерам, фактам и планам их участия в политической жизни и попыткам избрания в органы государственной власти и местного самоуправления.

Эффективность системы общегосударственных мер дополняется специальными мерами противодействия правоохранительных органов продвижению организованными преступными группами своих кандидатов в органы государственной власти и местного самоуправления в условиях выборов. Специальные меры предусматривают приобретение источников из числа представителей организованных преступных групп среднего и руководящего звена с целью добывания информации о планах, кадровом составе преступных групп, должностных лицах государственных и муниципальных органов, оказывающих преступным группам содействие в осуществлении противоправной деятельности, об источниках и каналах незаконного финансирования выборов и политической деятельности, направленной на нанесение ущерба безопасности Российской Федерации. Важное значение имеет работа в «околокриминальной» среде по добыванию информации о связях кандидатов, представляющих интересы организованных преступных групп, с функционерами политических партий, членами избирательных комиссий, сотрудниками правоохранительных органов, о фактах коррупции в политических партиях, общественных организациях, государственных и муниципальных органах.

Неотъемлемой составляющей специальных мер является последовательное документирование организованной преступной деятельности в целях подготовки материалов для привлечения лидеров и 
участников преступных групп к уголовной ответственности. Следует констатировать, что в современных условиях документирование организованной преступной деятельности осуществляется не в полном объеме $^{19}$. В настоящее время более $60 \%$ сотрудников правоохранительных органов уверены, что в уголовных делах отражаются только некоторые эпизоды преступной деятельности отдельных участников преступных формирований, причем деятельность самих преступных формирований вообще не рассматривается ${ }^{20}$. Необходимым условием оперативного документирования противоправной деятельности является обеспечение безопасности задействованных сотрудников правоохранительных органов и оперативных источников. В качестве конечного результата следует рассматривать ликвидацию организованных преступных групп (задержание с поличным, арест и привлечение к уголовной ответственности организаторов и участников преступных групп).

Отдельным направлением работы является документирование деятельности организованных преступных групп, имеющих международные связи. В целях повышения качества документирования и подготовки принятия адекватных мер противодействия криминалитету важно развивать информационный обмен с Интерполом, Бюро по координации борьбы с организованной преступностью стран СНГ, зарубежными спецслужбами и правоохранительными органами.

Участие организованных преступных групп в избирательных кампаниях должно уступить место цивилизованным законным формам политической деятельности в Российской Федерации.

Красинский Владислав Вячеславович кандидат юридических наук, эксперт Российского общественного института избирательного права (РОИИП)

19 В связи с этим в структуре Генеральной прокуратуры или Совета Безопасности Российской Федерации представляется целесообразным создать единый Аналитический центр, в котором бы накапливалась и систематизировалась информация о противоправной деятельности российских организованных преступных групп во всех субъектах Федерации и за рубежом, о фактах проникновения представителей криминалитета в органы государственной власти и местного самоуправления, об избранных в органы государственной власти и местного самоуправления лидерах и участниках организованных преступных групп, о ходе предварительного расследования и судебном рассмотрении уголовных дел по составам преступлений, предусмотренных ст.ст. 208-210 УК РФ. Руководителя данного Центра предлагается наделить обязанностью регулярного информирования Президента и руководителей высших государственных органов о реальной криминогенной обстановке в Российской Федерации, угрозах безопасности Российской Федерации со стороны организованных преступных групп и принимаемых мерах по борьбе с организованной преступностью.

${ }^{20}$ См.: Юикова Е.M. Преступность в сфере функционирования криминальной среды и ее изменения / Преступность в России и борьба с ней: региональный аспект. М., Российская криминологическая ассоциация, 2003. С. 21. 